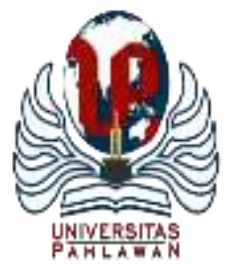

Edukatif : Jurnal Ilmu Pendidikan Volume 4 Nomor 1 Tahun 2022 Halm 380 - 389 EDUKATIF: JURNAL ILMU PENDIDIKAN

Research \& Learning in Education

https://edukatif.org/index.php/edukatif/index

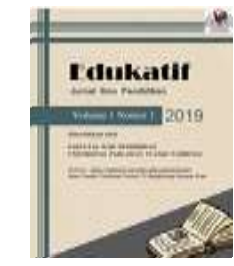

\title{
Efektivitas Penerapan Model Pembelajaran Berbasis E-Learning Berbantuan LKPD Elektronik Terhadap Hasil Belajar Peserta Didik
}

\author{
Rizky Ramadhana ${ }^{1 凶}$, Abdul Hadi ${ }^{2}$ \\ STKIP YPUP Makassar, Indonesia ${ }^{1,2}$ \\ E-mail : rizkyramadhana53@gmail.com ${ }^{1}, \underline{\text { abdulhadi030786@ gmail.com }}^{2}$
}

\begin{abstract}
Abstrak
Latar belakang penelitian ini adalah kendala dalam melaksanakan pembelajaran secara daring yaitu guru merasa kesulitan menyampaikan materi kepada peserta didik begitupun peserta didik banyak yang mengeluhkan tentang sulitnya mereka memahami materi pembelajaran matematika. Penelitian ini bertujuan untuk mengetahui apakah penerapan model pembelajaran berbasis e-learning berbantuan LKPD elektronik efektif terhadap hasil belajar peserta didik. Adapun jenis penelitian ini adalah jenis penelitian pre-eksperimen dengan desain penelitian yang digunakan adalah One-Group Pretest Posttest Design,yang dilaksanakan di MA Ihya' Ulumiddin Kampung Beru dengan populasi penelitian adalah seluruh peserta didik kelas XI, sampel penelitian ini adalah keseluruhan dari populasi. Hasil penelitian menunjukkan hasil belajar matematika peserta didik kelas XI MA Ihya' Ulumiddin Kampung Beru sebelum menerapkan model pembelajaran berbasis E-Learning berbantuan LKPD elektronik dikategorikan sangat rendah dengan rata-rata 49,56 dan standar deviasinya 17,92. Sedangkan hasil belajar matematika setelah menerapkan model pembelajaran berbasis E-Learning berbantuan LKPD elektronik dikategorikan tinggi dengan rata-rata 86,11 dan standar deviasinya 8,92. Aktivitas peserta didik selama pembelajaran sebesar $82,41 \%$ yang berada pada kategori baik. Keterlaksanaan pembelajaran sebesar $81,48 \%$. Persentase respon peserta didik sebesar $70,99 \%$ yang berarti berada pada kategori cukup positif. Dari hasi penelitian disimpulkan bahwa penerapan model pembelajaran berbasis e-learning berbantuan LKPD elektronik efektif terhadap hasil belajar peserta didik.
\end{abstract}

Kata Kunci: efektivitas, model pembelajaran berbasis e-learning, LKPD elektronik.

\section{Abstract}

The background of this research is an obstacle in carrying out online learning, namely teachers find it difficult to convey material to students as well as many students complain about their difficulty in understanding mathematics learning materials. This study aims to determine whether the application of e-learning based learning model assisted by electronic LKPD is effective on student learning outcomes. The type of this research is a type of pre-experimental research with the research design used is One-Group Pretest Posttest Design, which was carried out at MA Ihya' Ulumiddin Kampung Beru with the research population being all students of class XI, the sample of this study was the entire population. The results showed that the mathematics learning outcomes of students in class XI MA Ihya' Ulumiddin Kampung Beru before applying the E-Learning-based learning model assisted by electronic LKPD were categorized as very low with an average of 49.56 and a standard deviation of 17.92. Meanwhile, the learning outcomes of mathematics after applying the E-Learning-based learning model assisted by electronic LKPD are categorized as high with an average of 86.11 and a standard deviation of 8.92. The activity of students during learning is $82.41 \%$ which is in the good category. The implementation of learning is $81.48 \%$. The percentage of student responses is $70.99 \%$, which means it is in the quite positive category. From the results of the study, it was concluded that the application of the e-learning based learning model assisted by the electronic LKPD was effective on student learning outcomes.

Keywords: effectivity, learning model based e-learning, electronic LKPD

Copyright (c) 2022 Rizky Ramadhana, Abdul Hadi

$\triangle$ Corresponding author

Email : rizkyramadhana53@gmail.com

DOI $\quad$ : https://doi.org/10.31004/edukatif.v4i1.1778

ISSN 2656-8063 (Media Cetak)

ISSN 2656-8071 (Media Online) 
381 Efektivitas Penerapan Model Pembelajaran Berbasis E-Learning Berbantuan LKPD Elektronik Terhadap Hasil Belajar Peserta Didik - Rizky Ramadhana, Abdul Hadi

DOI: https://doi.org/10.31004/edukatif.v4i1.1778

\section{PENDAHULUAN}

Pendidikan merupakan hal penting dalam kehidupan manusia yang secara langsung mempengaruhi seluruh kehidupannya. Suatu kenyataan yang membuktikan bahwa pendidikan adalah instrumen utama bagi pembangunan kehidupan umat manusia dengan berbagai hasil yang telah diraihnya dan sebuah kenyataan bahwa peradaban umat manusia dapat dibangun dengan adanya pendidikan. Tanpa pendidikan manusia tidak mengetahui apa yang mereka tidak ketahui (Yusuf, 2018).

Tetapi saat ini dunia pendidikan dihadapkan pada tantangan pembelajaran dimasa pandemi covid-19. Virus Corona merupakan wabah yang mengakibatkan kegiatan belajar mengajar di sekolah ataupun perguruan tinggi yang biasanya dilaksanakan secara tatap muka berubah menjadi kegiatan pembelajaran yang dilaksanakan secara daring atau online. Hal ini tentunya membutuhkan penyesuaian baik dari segi peserta didik maupun dari segi guru sebagai pendidik.

Sistem pembelajaran dilakukan jarak jauh dengan memanfaatkan teknologi informasi. Hal ini tentunya menjadi tantangan tersendiri bagi seorang guru karena masih banyak guru belum terbiasa menggunakan sistem pembelajaran daring. Pandemi covid-19 ini mengharuskan seorang guru menjadi terampil dalam menyajikan materi ajarnya yang tentunya harus menggunakan media yang mendukung pembelajaran secara daring.

Salah satu sekolah yang juga melakukan pembelajaran jarak jauh via daring adalah MA Ihya Ulumiddin Kampung Beru, namun ada beberapa kendala dalam melaksanakan pembelajaran secara daring yaitu guru merasa kesulitan menyampaikan materi kepada peserta didik begitu pun peserta didik banyak yang mengeluhkan tentang sulitnya mereka memahami materi pembelajaran terutama mata pelajaran matematika, hal ini membuat peserta didik cenderung acuh tak acuh terhadap pembelajaran, kurang aktif dalam kegiatan belajar mengajar secara daring sehingga mengakibatkan hasil belajar mereka rendah.

Model pembelajaran berbasis e-learning menjadi salah satu alternatif yang dapat dimanfaatkan oleh guru di masa pandemi covid-19. E-learning merupakan pembelajaran yang menggunakan jasa elektronika sebagai alat bantunya. Menurut Tambunan e-learning adalah pembelajaran yang pelaksanaannya didukung oleh jasa teknologi seperti telepon, audio, videotape, transmisi satelite atau komputer. E-learning bukan sekadar bermain dan berselancar di dunia maya, klik sana-sini untuk pindah dari satu situs ke situs lain, mendownload, berlatih, mencerna, menjawab pertanyaan, menemukan, dan menyebabkan dirinya berubah, menjadi lebih cerdas, menjadi dapat belajar lebih banyak lagi.

Selain pembelajaran berbasis e-learning, media pembelajaran juga diharapkan dapat membantu guru dan peserta didik. Musfiqon(Mashuri, 2019) menyatakan media merupakan alat bantu yang digunakan oleh guru dengan desain yang disesuaikan untuk meningkatkan kualitas pembelajaran. Oleh karena itu, peran media dalam proses pembelajaran menjadi penting karena akan menjadikan proses pembelajaran tersebut menjadi lebih bervariasi dan tidak membosankan.

Media pembelajaran yang sering digunakan di sekolah adalah LKPD (Lembar Kerja Peserta Didik). Depdiknas(Departemen Pendidikan Nasional, 2004) mengartikan LKPD sebagai lembaran-lembaran berisi tugas yang harus dikerjakan oleh peserta didik, biasanya berupa petunjuk atau langkah-langkah untuk menyelesaikan suatu tugas dan tugas tersebut haruslah jelas kompetensi dasar yang akan dicapai. Selanjutnya Arief(Arief, 2015) menyatakan bahwa "LKPD merupakan salah satu sarana untuk membantu dan mempermudah dalam kegiatan pembelajaran sehingga akan terbentuk interaksi yang efektif antara peserta didik dengan guru, dan dapat meningkatkan aktifitas peserta didik dalam peningkatan prestasi belajar". Akan tetapi LKPD dalam bentuk cetak masih belum efektif dan kurang praktis dalam penggunaannya, sehingga untuk mengoptimalkan penggunaan LKPD dalam pembelajaran daring diperlukan LKPD elektronik dimana peserta didik dapat mengakses LKPD tersebut tanpa harus datang ke sekolah untuk mengambil LKPD cetak. 
382 Efektivitas Penerapan Model Pembelajaran Berbasis E-Learning Berbantuan LKPD Elektronik Terhadap Hasil Belajar Peserta Didik - Rizky Ramadhana, Abdul Hadi

DOI: https://doi.org/10.31004/edukatif.v4i1.1778

Berdasarkan uraian di atas maka penulis akan membahas masalah ini lebih lanjut dan mengangkatnya dalam satu tulisan dengan judul "Efektivitas Penerapan Model Pembelajaran Berbasis E-Learning Berbantuan LKPD Elektronik Terhadap Hasil Belajar Peserta Didik Ma Ihya Ulumiddin Kampung Beru".

Pada penelitian sebelumnya (Dandi, 2021) mengatakan bahwa pembelajaran daring (e-learning) dapat meningkatkan kualitas pembelajaran, pembelajaran daring (e-learning) dapat memberi akses terhadap peserta didik dalam melakukan pembelajarn dan guru dapat memberikan pembelajaran meskipun tidak dalam kelas. Model pembelajaran e-Learning prinsipnya adalah pembelajaran melalui pemanfaatan TI berbasis teknologi komputer dan atau internet. Teknologi pembelajaran seperti ini juga disebut dengan pembelajaran berbasis web (Web-Based Instruction). Dalam konteks jaringan, e-Learning didefinisikan sebagai upaya menghubungkan peserta didik dengan guru secara fisik terpisah dan berjauhan, dimana interaktivitas dalam hubungan tersebut dilakukan secara langsung maupun tidak langsung. secara sederhana dapatlah dikatakan bahwa pembelajaran elektronik (e-learning) merupakan kegiatan pembelajaran yang memanfaatkan jaringan Internet sebagai metode penyampaian, interaksi, dan fasilitasi serta didukung oleh berbagai bentuk layanan belajar lainnya. Sistem atau konsep pendidikan yang memanfaatkan teknologi informasi dalam proses belajar mengajar dapat disebut sebagai suatu modelpembelajaran e-learning (Hadisi \& Muna, 2015). Diperkuat lagi oleh(Hanifah et al., 2019) model pembelajaran e-learning adalah sistem pembelajaran elektronik atau pembelajaran (Electronic learning disingkat e-learning) adalah bentuk teknologi informasi yang digunakan dalam pendidikan sekolah dunia maya. Sehingga dapat disimpulkan bahwa model pembelajaran e-learning merupakan salah satu sistem pembelajaran teknologi informasi atau sistem pembelajaran elektronik berbasis web dengan bantuan internet (jaringan) yang dapat membantu peserta didik untuk menambah informasi tentang konsep yang dipelajari.

Dalam penelitian ini, penerapan pembelajaran berbasis e-learning dilaksanakan dengan bantuan penggunaan LKPD elektronik. LKPD adalah salah satu bahan ajar yang berisi rangkuman mengenai pembelajaran yang dilaksanakan dan berisikan langkah kerja yang di tugaskan kepada peserta didik. LKPD ini tetap mengacu pada kompetensi pembelajaran sehingga tujuan pembelajaran dapat tercapai (Prastowo, 2015). Trianto (Novelia, 2016) LKPD adalah bahan ajar yang berisikan panduan untuk peserta didik dalam kegiatan penyelidikan atau pemecahan masalah. LKPD memuat petunjuk kegiatan dan langkah-langkah yang harus dilakukan peserta didik untuk menyelesaikan tugas yang diberikan sehingga indikator pencapaian pembelajaran dapat tercapai secara maksimal. Berdasarkan pendapat di atas dapat disimpulkan bahwa LKPD adalah suatu bahan ajar berisi serangkaian langkah kerja atau petumjuk pelaksanaan tugas yang harus dikerjakan peserta didik untuk mengoptimalkan pemahaman konsep dan penguasaan materi berdasarkan kompetensi dan indikator sesuai tujuan pembelajaran yang ditempuh.

Salah satu bentuk LKPD yaitu peggunaan LKPD elektronik, dimana LKPD elektronik merupakan lembaran latihan peserta didik yang dikerjakan secara digital dan dilakukan secara sistematis serta berkesinambungan selama jangka waktu tertentu (Ramlawati et al., 2014). LKPD elektronik ini dapat dirancang dan dikreasikan sesuai dengan tujuan yang ingin dicapai dalam proses pembelajaran serta kreativitas masing-masing guru, dimana nantinya peserta didik dapat mengakses LKPD elektronik ini melalui jaringan internet dengan harapan dapat membantu peserta didik untuk lebih memahami materi yang diberikan oleh guru sehingga tujuan pembelajaran dapat tercapai.

Berdasarkan latar belakang masalah yang telah dibahas, maka rumusan masalah dalam penelitian ini adalah "apakah penerapan model pembelajaran berbasis e-learning berbantuan LKPD elektronik efektif terhadap hasil belajar peserta didik MA Ihya Ulumiddin Kampung Beru?".

Adapun tujuan yang ingin dicapai dalam penelitian ini adalah untuk mengetahui apakah penerapan model pembelajaran berbasis e-learning berbantuan LKPD elektronik efektif terhadap hasil belajar peserta didik MA Ihya Ulumiddin Kampung Beru. 
383 Efektivitas Penerapan Model Pembelajaran Berbasis E-Learning Berbantuan LKPD Elektronik Terhadap Hasil Belajar Peserta Didik - Rizky Ramadhana, Abdul Hadi

DOI: https://doi.org/10.31004/edukatif.v4i1.1778

Fokus penelitian ini adalah penerapan pembelajaran berbasis e-learning dengan berbantuan LKPD elektronik. Selama ini penelitian yang ada hanya pada penggunaan e-learning saja atau LKPD saja tetapi belum ada yang meneliti tentang efektivitas pembelajaran berbasis e-learning berbantuan LKPD elektronik. Mengacu pada kondisi dimasa pandemic covid 19 dimana pembelajaran dilakukan secara daring sehingga diperlukan adanya pembaruan dalam melaksanakan kegiatan belajar mengajar, salah satunya dengan memanfaatkan pembelajaran berbasis e-learning dan menggunakan LKPD elektronik sebagai media pembelajaran.

\section{METODE PENELITIAN}

Penelitian ini adalah jenis penelitian pre-eksperimen. Penelitian pre-eksperimen adalah suatu metode penelitian yang berusaha mencari hubungan variabel tertentu terhadap variabel lain dan kondisi yang berkontrol secara ketat. Dengan desain penelitian akan penelitian ini adalah sebagai berikut:

Tabel 1.One-Group Pretest Posttest Design

\begin{tabular}{ccc}
\hline $\mathbf{0}_{\mathbf{1}}$ & $\mathbf{X}$ & $\mathbf{0}_{\mathbf{2}}$ \\
\hline Pretest & Perlakuan & Posttest \\
\hline (Lestari \& Yudhanegara, 2015) &
\end{tabular}

Keterangan :

$0_{1}=$ pre-test untuk mengukur hasil belajar peserta didik sebelum diterapkan model pembelajaran berbasis elearning berbantuan LKPD elektronik

$\mathrm{X}=$ Treatment (perlakuan) berupa pengajaran dengan menggunakan model pembelajaran berbasis e-learning berbantuan LKPD elektronik

$0_{2}=$ Post-test untuk mengetahui hasil belajar peserta didik setelah diterapkan model pembelajaran berbasis e-learning berbantuan LKPD elektronik

Penelitian ini dilaksanakan MAS Ihya Ulumiddin Kampung Beru dengan populasi penelitian ini adalah seluruh peserta didik kelas XI MA Ihya Ulumiddin Kampung Beru Tahun Ajaran 2020/2021. Sampel penelitian ini adalah keseluruhan dari populasi.

Menurut (Jeranah, 2017) teknik pengumpulan data terdiri dari 4 indikator yaitu :

1. Tes hasil belajar

Teknik pengumpulan data dalam penelitian ini adalah memberikan tes hasil belajar sebelum (pretest) dan setelah (postest) diberikan perlakauan berdasarkan soal yang dibuat peneliti sendiri. Peneliti bersama dengan bantuan guru untuk mengawasi peserta didik dalam mengerjakan tes. Hasil tes merupakan data hasil penelitian.

2. Lembar observasi aktivitas peserta didik

Lembar observasi aktivitas peserta didik merupakan instrumen yang digunakan untuk memperoleh data tentang aktivitas peserta didik selama proses pembelajaran berlangsung. Lembar observasi peserta didik yang digunakan pada penelitian ini adalah observasi skala penilaian (rating scale).

3. Lembar angket respon peserta didik

Lembar angket peserta didik digunakan untuk mengumpulkan data tentang respon peserta didik terhadap perangkat pembelajaran dan proses pembelajaran yang berlangsung. Adapun indikator respon peserta didik yang digunakan adalah tanggapan peserta didik yang berhubungan dengan kesenangan, motivasi, kejelasan, ketertarikan dan persetujuan terhadap pembelajaran yang diharapkan pada masing-masing peserta didik. 
384 Efektivitas Penerapan Model Pembelajaran Berbasis E-Learning Berbantuan LKPD Elektronik Terhadap Hasil Belajar Peserta Didik - Rizky Ramadhana, Abdul Hadi

DOI: https://doi.org/10.31004/edukatif.v4i1.1778

4. Keterlaksanaaa Pembelajaran

Keterlaksanaaan Pembelajaran merupakan instrumen yang digunakan untuk memperoleh data tentang peneliti selama proses pembelajaran berlangsung.

Teknik analisis data yamg digunakan dalam penelitian ini adalah menggunakan statistik deskriptif dan uji gain.

1. Statistik Deskriptif

a. Hasil belajar matematika

Analisis statistik deskriptif digunakan untuk mendeskripsikan skor hasil belajar matematika yang diperoleh dari tes hasil belajar peserta didik. Untuk keperluan analisis digunakan tabel distribusi frekuensi, rata-rata, standar deviasi, median, modus,rentang dan skor ideal.

Data berupa hasil belajar selanjutnya dikategorikan menurut prosedur berikut:

Tabel 2. Pengkategorian Nilai Dari Hasil Belajar Matematika

\begin{tabular}{cc}
\hline Tingkat Penguasaan & Kategori \\
\hline $92-100$ & Sangat baik \\
$84-91$ & Tinggi \\
$76-83$ & Sedang \\
$68-75$ & Rendah \\
$0-67$ & Sangat rendah \\
\hline
\end{tabular}

b. Aktivitas Peserta Didik

Data hasil pengamatan aktivitas peserta didik dianalisis secara kuantitatif dan kualitatif. Analisis kuantitatif yaitu dengan menentukan presentase frekuensi. Langkah-langkah analisis kuantitatif aktivitas peserta didik adalah sebagai berikut:

1. Menentukan frekuensi hasil pengamatan aktivitas peserta didik untuk setiap kegiatan dalam setiap pertemuan.

2. Mencari persentase frekuensi aktivitas peserta didik dengan membagi besarnya frekuensi dengan jumlah frekuensi untuk semua indikator, kemudian dikalikan $100 \%$.

Dari penjeiasan di atas, untuk mencari presentase aktivitas pembelajaran dapat dirumuskan sebagai berikut.

\begin{tabular}{|c|c|c|}
\hline Nilai $=$ & & $\frac{\text { jumlah frekunsi setiap indikator }}{100 \%}$ \\
\hline & \multicolumn{2}{|c|}{ Tabel 3. Kategori Aktivitas Peserta Did } \\
\hline & $\begin{array}{c}\text { Presentase } \\
(\%)\end{array}$ & Kategori \\
\hline & $90<x \leq 100$ & Sangat baik \\
\hline & $75<x \leq 90$ & Baik \\
\hline & $60<x \leq 75$ & Kurang baik \\
\hline & $40<x \leq 60$ & Tidak baik \\
\hline & $0 \leq \mathrm{x} \leq 40$ & Sangat tidak baik \\
\hline
\end{tabular}

c. Respon peserta didik

Data tentang respon peserta didik di peroleh dari angket respon peserta didik terhadap kegiatan pembelajaran, selanjutnya diatalisis secara kuantitatif dan kualitatif. Kegiatan yang di lakukan untuk menganalisis respon peserta didik adalah menghitung banyaknya peserta didik yang memberi respon sesuai 
dengan aspek yang ditanyakan, kemudian menhitung persentasenya. Langkah-langkah analisis respon peserta didik adalah sebagai berikut:

1. Menenukan frekuensi hasil pengamatan respon peserta didik

2. Mencari presentase dengan jumlah frekuensi untuk semua indikator, kemudian dikalikan $100 \%$

$$
\text { Nilai }=\frac{\text { banyaknya frekuensi }}{\text { jumlah frekuensi setiap indikator }} \times 100 \%
$$

\section{Tabel 4. Kategori Respon Peserta Didik}

\begin{tabular}{cc}
\hline Presentase (\%) & Kategori \\
\hline $90<\mathrm{x} \leq 100$ & Sangat positif \\
\hline $75<\mathrm{x} \leq 90$ & Positif \\
\hline $60<\mathrm{x} \leq 75$ & Cukup positif \\
\hline $40<\mathrm{x} \leq 60$ & Kurang positif \\
\hline $0 \leq \mathrm{x} \leq 40$ & Sangat kurang positif \\
\hline
\end{tabular}

d. Keterlaksanaan pembelajaran

Keterlaksanaan pembelajaran merupakan data tentang pencapaian peneliti dalam pemberian perlakuan di dalam kelas, sehingga di dalam pelaksanan pembelajaran benar-benar sesuai dengan kondisi dan proses yang diharapkan. Dalam penelitian ini keberhasilan keterlaksanaan pembelajaran apabila aktivitas peneliti telah terlaksana saat pembelajaran dengan nominal baik.

Langkah-langkah analisis kuantitatif keterlaksanaan pembelajaran adalah sebagai berikut

a. Menentukan prekuensi hasil pengamatan aktivitas peneliti untuk setiap kegiatan

b. Mencari presentase frekuensi keterlaksanaan pembelajaran yaitu dengan membagi besarnya frekuensi dengan jumblah frekuensi untuk semua indikator kemudian dikalikan $100 \%$

$$
\text { Presentase }=\frac{\text { jumlah tanda cek pada kolom ya }}{\text { jumlah total tanda cek }}=100 \%
$$

Adapun pengkategorian keterlaksanaan pembelajaran sesuai dengan tabel 3.5 berikut:

Tabel 5. Kategori Keterlaksanan Pembelajaran

\begin{tabular}{ccc}
\hline No & Keterlaksaan $(\%)$ & Kategori \\
\hline 1 & $90<\mathrm{x} \leq 100$ & Sangat baik \\
2 & $75<\mathrm{x} \leq 91$ & Baik \\
3 & $50<\mathrm{x} \leq 75$ & Sedang \\
4 & $25<\mathrm{x} \leq 50$ & Kurang \\
5 & $0<\mathrm{x} \leq 25$ & Sangat kurang \\
\hline
\end{tabular}

\section{e. Uji Gain}

Data $\mathrm{N}$-gain atau gain ternomalisasi merupakan data yang diperoleh dengan membandingkan selisi skor postest dan pretest dengan selisi SMI dan pretest .Selain digunakan untuk melihat peninkatan kemampuan peserta didik, data ini juga memberikan informasi mengenai pencapaian kemampuan peserta didik. Uji gain ini dilakukan untuk melihat keefektifan dari Model pembelajaran berbasis E-Learning berbantuan LKPD elektronikterhadap prestasi belajar matematika peserta didik pada kelas sampel dari data pretest dan posttest dengan mengunakan rumus Gain (Lestari \& Yudhanegara, 2015).

$$
\mathrm{N}-\text { Gain }=\frac{\text { skorpostest-skorpretest }}{\text { SMI-skorpretest }}
$$


Tabel 6. kriteria nilai $\mathbf{N}$ - Gain

\begin{tabular}{cc}
\hline Nilai $\mathbf{N}-$ Gain & Kriteria \\
\hline $\mathrm{N}-$ gain $\geq 0,70$ & Tinggi \\
\hline $0,30<\mathrm{N}-$ gain $<0,70$ & Sedang \\
\hline $\mathrm{N}-$ gain $\leq 0,30$ & Rendah \\
\hline
\end{tabular}

Efektivitas merupakan stadar atau taraf tercapainya suatu tujuan dengan rencana yang telah ditetapkan sebelumnya maka perluh diterapkan kriteria keefektivan dalam penelitian ini. Kriteria keefektifan penelitian ini mengacu pada:

1. Hasil belajar matematika peserta didik setelah penerapan model pembelajaran berbasis e-learning berbantuan LKPD elektronik mencapai kkm yaitu 76.

2. Peningkatan hasil belajar sebelum dan sesudah penerapan model pembelajaran berbasis e-learning berbantuan LKPD elektronik mencapai kategori sedang.

3. Aktivitas peserta didik selama pembelajaran matematika dengan penerapan pendekatan induktif development pada kategori baik.

4. Respon peserta didik setelah pembelajaran matematika dengan penerapan model pembelajaran berbasis ELearning berbantuan LKPD elektronikpada kategori cukup positif.

5. Keterlaksanaan pembelajaran minimal berada pada kategori baik.

\section{HASIL DAN PEMBAHASAN PENELITIAN}

\section{Hasil Penelitian}

a. Hasil Analisis Deskriptif

Berdasarkan data skor hasil belajar peserta didik sebelum diajar dengan model pembelajaran berbasis $e$ learning berbantuan lkpd elektronik diperoleh rata-rata skor hasil belajar dari 18 peserta didik adalah 49,56 dengan varians 321,20 , standar deviasi 17,92 , nilai yang dicapai peserta didik tersebut dengan nilai terendah 13 yang merupakan nilai terendah yang mungkin dicapai 0 dan nilai tertinggi 76 yang merupakan nilai tertinggi dari nilai tertinggi yang mungkin dicapai 100. Adapun kategori kemampuan peserta didik sebelum diajar dengan model pembelajaran berbasis e-learning berbantuan lkpd elektronik pada umumnya berada pada kategori sangat rendah dengan persentase $72,2 \%$, sedangkan yang lainnya berada pada kategori rendah dan sedang, untuk kategori rendah sebanyak 22,2\% dan kategori sedang sebanyak 5,6\% dari jumlah keseluruhan peserta didik.

Selanjutnya, berdasarkan dataskor hasil belajar peserta didik setelah diajar dengan model pembelajaran berbasis e-learning berbantuan lkpd elektronik diperoleh rata-rata skor hasil belajar adalah 86,11dengan varians 79,63 , standar deviasi 8,92 , nilai yang dicapai peserta didik tersebut dengan nilai terendah 71 yang merupakan nilai terendah yang mungkin dicapai 0 dan nilai tertinggi 100 yang merupakan nilai tertinggi dari nilai tertinggi yang mungkin dicapai 100. Adapun kategori kemampuan peserta didik setelah diajar dengan model pembelajaran berbasis e-learning berbantuan lkpd elektronik pada umunnya berada pada kategori sedang dan tinggi dengan persentase $33,3 \%$, sedangkan yang lainnya berada pada kategori rendah dan sangat tinggi, untuk kategori rendah sebanyak 5,6\% dan kategori sangat tinggi sebanyak $27,8 \%$ dari jumlah keseluruhan peserta didik.

Hasil pengamatan aktivitas peserta didik selama pembelajaran dengan penerapan model pembelajaran berbasis E-Learning berbantuan LKPD elektronik menunjukkan persentase rata-rata aktivitas peserta didik yaitu $82,41 \%$. Mengacu pada kategori aktivitas pada tabel 3, hal ini menunjukkan bahwa aktivitas peserta didik selama proses pembelajaran berlangsung berada pada kategori baik. 
387 Efektivitas Penerapan Model Pembelajaran Berbasis E-Learning Berbantuan LKPD Elektronik Terhadap Hasil Belajar Peserta Didik - Rizky Ramadhana, Abdul Hadi

DOI: https://doi.org/10.31004/edukatif.v4i1.1778

Angket respon peserta didik digunakan untuk mengetahui seberapa besar tanggapan atau reaksi peserta didik terhadap pembelajaran dengan menerapkan model pembelajaran berbasis e-learning berbantuan LKPD elektronik. Kegiatan yang dilakukan untuk menganalisis respon peserta didik adalah menghitung banyaknya peserta didik yang memberi respon sesuai dengan aspek yang ditanyakan kemudian menghitung persentasenya. Hasil analisis respon peserta didik yaitu dari angket respon peserta didik yang diberikan kepada 18 peserta didik dengan jumlah pertanyaan sebanyak 9 pertanyaan yang bersifat positif setelah mengikuti pelajaran dengan menggunakan model pembelajaran berbasis e-learning berbantuan LKPD elektronik diperoleh rata-rata sebesar 70,99\%. Mengacu pada kategori aktivitas pada tabel 4 menunjukkan bahwa respon peserta didik terhadap proses pembelajaran berada pada kategori cukup positif.

Keterlaksanaan pembelajaran dengan menerapkan model pembelajaran berbasis e-learning berbantuan LKPD elektronik menunjukkan rata-rata persentase keterlaksanaan pembelajaran yaitu $81,48 \%$. Mengacu pada kategori aktivitas pada tabel 5 menunjukkan bahwa keterlaksanaan pembelajaran selama proses pembelajaran berlangsung berada pada kategori baik.

Uji gain ini dilakukan untuk melihat peningkatan hasil belajar peserta didik sebelum (pretest) dan setelah (posttest) menerapkan pendekatan induktif development. Penggunaan rumus uji gain diperoleh nilai gain ternomalisasi 0,70. Dimana mengacu pada kriteria nilai pada gain pada tabel 6, maka dapat disimpulkan bahwa peningkatan hasil belajar peserta didik sebelum (pretest)dan setelah (posttest)dengan menerapkan model pembelajaran berbasis e-learning berbantuan LKPD elektronik berada pada kategori tinggi.

\section{Pembahasan}

Dalam penelitian ini, kriteria efektivitas penerapan model pembelajaran berbasis e-learning berbantuan LKPD elektronikditinjau dari empat aspek yaitu:

Hasil belajar matematika adalah gambaran tingkat penguasaan peserta didik dalam belajar matematika yang terlihat pada nilai yang diperoleh dari tes hasil belajar matematika. Dalam hal ini, penerapan model pembelajaran berbasis e-learning berbantuan LKPD elektronik dikatakan efektif apabila peserta didik mencapai ketuntasan belajar minimum. Berdasarkan hasil analisis deskriptif diperoleh rata-rata skor pre-test peserta didik kelas XI MA Ihya Ulumiddin sebesar 49,56 dengan standar deviasi 17,92 berada pada kategori sangat rendah sedangkan rata-rata skor post-test peserta didik sebesar 86,11 dengan standar deviasi 8,92 berada pada kategori tinggi. Hal ini menunjukkan bahwa terjadi peningkatan dari rata-rata skor hasil belajar matematika peserta didik setelah menerapkan model pembelajaran berbasis e-learning berbantuan LKPD elektronik. Sedangkan untuk nilai gain hasil belajar menunjukkan bahwa hasil uji normal gain diperoleh sebesar 0,70 dengan kategori sedang. Dari Hasil analisis dapat dikatakan bahwa penerapan model pembelajaran berbasis e-learning berbantuan LKPD elektronik sangat baik dalam upaya peningkatan hasil belajar peserta didik. Hal tersebut dikarenakan pada pembelajaran e-learning berbantuan LKPD elektronik peserta didik dapat memahami materi dengan baik dan peserta didik menjadi lebih mudah untuk berkomunikasi dengan guru melalui fasilitas internet kapan saja bisa dilakukan tanpa dibatasi jarak, tempat dan waktu, sehingga membuat peserta didik dapat menanyakan hal-hal yang masih kurang dipahami, peran peserta didik pun berubah dari pasif menjadi aktif, dan hal ini juga dibantu dengan penggunaan LKPD elektronik sehingga peserta didik terbantu dalam belajarnya sehingga tujuan pembelajaran dapat dicapai.

Keterlaksanaan pembelajaran merupakan data tentang pencapaian pengajar dalam melaksanakan kegiatan mengajar di dalam kelas. Dari hasil penelitian diperoleh keterlaksanaan pembalajaran memperoleh hasil persentase sebesar 81,48\% yang menunjukkan bahwa keterlaksanaan pembelajaran menggunakan model pembelajaran berbasis E-Learning berbantuan LKPD elektronikberada pada kategori baik. Penggunaan model pembelajaran berbasis E-Learning berbantuan LKPD elektronik adalah suatu program pembelajaran yang didesain untuk membantu guru dalam hal mengoptimalkan pembelajaran peserta didik dimasa pandemi Covid 19 dimana pertemuan tatap muka diganti dengan menggunakan pembelajaran secara daring. Dalam proses 
388 Efektivitas Penerapan Model Pembelajaran Berbasis E-Learning Berbantuan LKPD Elektronik Terhadap Hasil Belajar Peserta Didik - Rizky Ramadhana, Abdul Hadi

DOI: https://doi.org/10.31004/edukatif.v4i1.1778

penerapannya, peneliti juga memanfaatkan LKPD dimana dalam LKPD ini berisi aktivitas yang dapat dilakukan oleh peserta didik untuk membantu mereka dalam mengeksplorasi materi yang mereka pelajari.

Untuk mengukur aktivitas peserta didik kelas XI MA Ihya Ulumiddin Kampung Beru selama menerapkan model pembelajaran berbasis E-Learning berbantuan LKPD elektronik, peneliti menggunakan lembar observasi aktivitas peserta didik selama perlakuan yang kemudian data dianalisis secara kualitatif dan kuantitatif untuk mengetahui persentasenya. Berdasarkan hasil analisis diperoleh persentase aktivitas belajar peserta didik sebesar $82,41 \%$, yang menunjukkan bahwa aktivitas belajar peserta didik dalam proses pembelajaran menggunakan model pembelajaran berbasis E-Learning berbantuan LKPD elektronik berada pada kategori baik. Aktivitas peserta didik yang aktif tentunya mempengaruhi motivasi dan hasil belajarnya.

Respons peserta didik dalam penelitian ini adalah tanggapan peserta didik tentang proses belajar mengajar yang telah dilakukan. Respons peserta didik dikatakan positif apabila tanggapan dan komentar peserta didik terhadap aspek yang ditanggapi bersifat positif. Respon peserta didik diukur menggunakan angket respon peserta didik dan dibagikan pada pertemuan terakhir setelah menerapkan model pembelajaran berbasis E-Learning berbantuan LKPD elektronik. Kemudian data dianalisis secara kualitatif dan kuantitatif untuk mengetahui persentasenya. Berdasarkan hasil analisis diperoleh persentase respon peserta didik sebesar $70,99 \%$, yang menunjukkan bahwa respon peserta didik terhadap pembelajaran setelah menerapkan model pembelajaran berbasis E-Learning berbantuan LKPD elektronikberada pada kategori cukup positif.

Berdasarkan kriteria-kriteria diatas disimpulkan bahwa model pembelajaran berbasis E-Learning berbantuan LKPD elektronik efektif diterapkan untuk meningkatkan hasil belajar matematika peserta didik kelas XI MA Ihya Ulumiddin Kampung Beru. Hal ini dapat dilihat dari hasil belajar peserta didik yang mengalami peningkatan, sesuai dengan pendapat (Trianto, 2013) menambahkan bahwa keefektifan pembelajaran adalah hasil guna yang diperoleh setelah pelaksanaan proses belajar mengajar. Selanjutnya aktivitas peserta didik menunjukkan partisipasi dan keaktifan peserta didik selama proses pembelajaran berlangsung dengan baik dan respon peserta didik terhadap Model pembelajaran berbasis E-Learning berbantuan LKPD elektronik bersifat baik. Hasil penelitian ini sejalan dengan hasil penelitian(Khusniyah, 2020) yang menyebutkan bahwa pembelajaran berbasis e-learning efektif dalam meningkatkan hasil belajar.

\section{KESIMPULAN}

Pembelajaran berbasis e-learning berbantuan LKPD elektronik efektif terhadap hasil belajar. Sebagaimana dari hasil penelitian diperoleh hasil belajar matematika peserta didik kelas XI MA Ihya Ulumiddin Kampung Beru sebelum menerapkan model pembelajaran berbasis E-Learning berbantuan LKPD elektronikdikategorikan sangat rendah. Hasil belajar matematika peserta didik kelas XI MA Ihya Ulumiddin Kampung Beru setelah menerapkan model pembelajaran berbasis E-Learning berbantuan LKPD elektronik dikategorikan tinggi. Aktivitas peserta didik selama pembelajaran model pembelajaran berbasis E-Learning berbantuan LKPD elektronik berada pada kategori baik. Keterlaksanaan pembelajaran dengan menerapkan model pembelajaran berbasi E-learning berbantuan LKPD berada pada kategori baik. Persentase respon peserta didik selama pembelajaran dengan model pembelajaran berbasis E-Learning berbantuan LKPD berada pada kategori cukup positif. Ada beberapa kelemahan dari pembelajaran berbasis E-learning ini yaitu tidak semua peserta didik memiliki smartphone untuk mengakses pembelajaran atau peserta didik memiliki smartphone tapi tidak memiliki kuota. Untuk mengatasi hal tersebut, maka peserta didik yang tidak memiliki smartphone dapat mengakses pembelajaran melalui laptop atau komputer ataukah dapat belajar bersama teman yang memiliki smartphone. Serta pada masa pandemi seperti ini ada program kuota belajar gratis dari pemerintah. 
DOI: https://doi.org/10.31004/edukatif.v4i1.1778

\section{DAFTAR PUSTAKA}

Arief, M. F. (2015). Pengembangan Lembar Kerja Siswa (Lks) Pada Pembelajaran Mekanika Teknik Dengan Pendekatan Kontekstual Untuk Peserta Didik Kelas X Tgb Smkn 1 Surabaya. Jurnal Pendidikan Teknik Bangunan, 1, 148-152.

Dandi, A. (2021). Efektivitas Pembelajaran Matematika Berbasis Daring (E-Learning) Terhadap Prestasi Belajar Siswa. Pi: Mathematics Education Journal, Vol.4 No.1, 31-36.

Departemen Pendidikan Nasional. (2004). Pedoman Umum Pengembangan Bahan Ajar Sekolah Menengah Atas. Departemen Pendidikan Nasional, Direktorat Pendidikan Menengah Umum.

Hadisi, L., \& Muna, W. (2015). Pengelolaan Teknologi Informasi Dalam Menciptakan Model Inovasi Pembelajaran (E-Learning). Al-Ta'dib, 8(1), 117-140.

Hanifah, H., Supriadi, N., \& Widyastuti, R. (2019). Pengaruh Model Pembelajaran E-Learning Berbantuan Media Pembelajaran Edmodo Terhadap Kemampuan Pemecahan Masalah Matematis Peserta Didik. Numerical: Jurnal Matematika Dan Pendidikan Matematika, 31-42.

Jeranah. (2017). Efektivitas Penerapan Strategi Think Talk Write (Ttw) Dalam Pembelajaran Matematika Ditinjau Dari Gaya Belajar Peserta Didik. Jurnal Stkip Ypup, 138.

Khusniyah, T. W. (2020). Efektivitas Elearning Terhadap Hasil Belajar Mahasiswa Pada Mata Kuliah Konsep Dasar Ips. Sap (Susunan Artikel Pendidikan), Vol. 4 No., 207-214.

Lestari, E. K., \& Yudhanegara, M. R. (2015). Penelitian Pendidikan Matematika. Pt. Refika Aditama.

Mashuri, S. (2019). Media Pembelajaran Matematika. Deepublish.

Novelia, R. (2016). Penerapan Matery Learning Berbantuan Lkpd Untuk Meningkatkan Hasil Belajar Matematika Peserta Didik Di Kelas Viii Smp Negeri 4 Kota Bengkulu. Jp2ms.

Prastowo, A. (2015). Panduan Kreatif Membuat Bahan Ajar Inovatif. Divapress.

Ramlawati, Liliasari, Martoprawiro, M. A., \& Wulan, A. R. (2014). The Effect Of Electronic Portfolio Assessment Model To Increase Of Student's Generic Science Skills In Practical Inorganic Chemistry. $J$. Educ. L, 8(3), 179-186.

Trianto. (2013). Mendesain Model Pembelajaran Inovatif-Progresif. Kencana Prenada Media Group.

Yusuf. (2018). Pengantar Ilmu Pendidikan. Lembaga Penerbit Kampus Iain Palopo. 